\title{
エクソソーム随伴導入型薬物送達システムの開発
}

\author{
山吉麻子 $a, b$
}

\section{Development of Novel Drug Delivery System Targeting Exosomal microRNA}

\author{
Asako Yamayoshi ${ }^{a, b}$ \\ aDepartment of Chemistry of Biofunctional Molecules, Graduate School of Biomedical Sciences, Nagasaki University; \\ 1-14 Bunkyo-machi, Nagasaki 852-8521, Japan: and ${ }^{b}$ PREST, Japan Science and Technology \\ Agency (JST); 4-1-8 Honcho, Kawaguchi, Saitama 332-0012, Japan.
}

(Received August 27, 2019)

\begin{abstract}
Recently, mRNAs and microRNAs (miRNAs) have been identified in exosomes, which can be taken up by neighboring or distant cells. These exosomal-miRNAs may regulate gene expression in recipient cells. miRNAs are a type of non-coding RNA that induce post-transcriptional gene silencing of their target genes and regulate a wide range of biological processes, including apoptosis, differentiation, metabolism, and cell proliferation. According to recent reports, aberrant expression of miRNAs is associated with most pathological disease processes, including carcinogenesis. Therefore circulating onco-miRs are considered as significant therapeutic targets for cancer therapy. However, there is no report to regulate the function of miRNAs in exosomes. In this study, we developed novel drug delivery system using anti-exosome antibody-oligonucleotide conjugates (ExomiR-Tracker) for functional inhibition of circulating miRNAs. The "ExomiR-Tracker" is the world's first innovative molecule that has targeting property for exosome-recipient cells and specifically delivers nucleic acid medicines to the target cells. We found that ExomiR-Tracker can bind to the surface of exosomes and that the complexes are introduced into exosome-recipient cells then inhibit the activity of miRNA. We showed that ExomiR-Tracker can accumulate in cancerous tumors after intravenous administration. Existing technologies have difficulties for introducing anti-miR into exosomes and extremely low possibility to deliver anti-miR to exosome-recipient cells after intravenous administration. However, we successfully developed useful inhibition technology against exosomal-miRNA.
\end{abstract}

Key words - exosome; nucleic acid drug; microRNA (miRNA); drug delivery system (DDS)

\section{1.はじめに}

がん細胞が分泌する『エクソソーム』と呼ばれる 小胞が，がんの転移において重要な役割を果たすこ とが明らとなった [Fig. 1(b)]. 1,2) エクソソームは がん細胞を含むすべての細胞から分泌される直径 $100 \mathrm{~nm}$ 程度の小胞であり, 発見当初は細胞の不要 物的な存在としか認知されておらず，その機能や存 在意義などは不明であった。しかし，2007 年に mRNA や microRNA（miRNA）などの遺伝子が内 包されて他の細胞へと受け渡されている可能性が示 唆され，急激に注目を浴びることとなった。 ${ }^{3)}$ とり

$a$ 長崎大学大学院医歯薬学総合研究科機能性分子化学分 野（干852-8521 長崎市文教町 1-14）， ${ }^{b}$ JST さきがけ (厂332-0012 埼玉県川口市本町 4-1-8)

e-mail: asakoy@nagasaki-u.ac.jp

本総説は, 日本薬学会第 139 年会シンポジウム S45 で 発表した内容を中心に記述したものである.
わけエクソソームに含まれる miRNA（exosomalmiRNA）は，がんの転移にも梁く関与しており， 新たな治療標的として注目されている. ${ }^{4-7)}$ miRNAの一般的な機能阻害法として, miRNA に相補的な配列を有する核酸（anti-miR 核酸）を 用いた手法が挙げられる。年しかしながら exosomal-miRNA はエクソソームに内包されているた め，ヒト体内に投与された anti-miR 核酸をエクソ ソーム内に送達するのは困難である。また近年, エ クソソームはすべての細胞や臟器に取り込まれるの ではなく，その効率に指向性があることが見い出さ れた。例えば，U251 細胞から採取したエクソソー ムは，親細胞である U251 細胞へは取り込まれる が，アストロサイトには取り込まれ難く，さらには この逆も然りで，アストロサイトから採取したエク ソソームは親細胞であるアストロサイトへは取り込 まれるが U251 細胞には取り込まれ難いという現象 
(a)

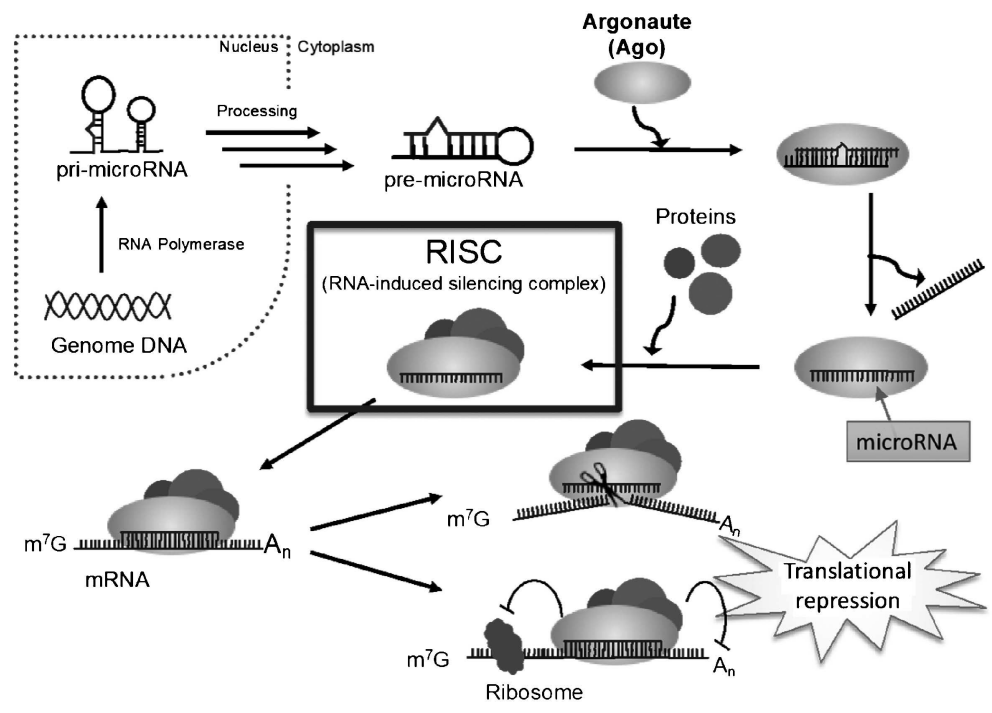

(b)

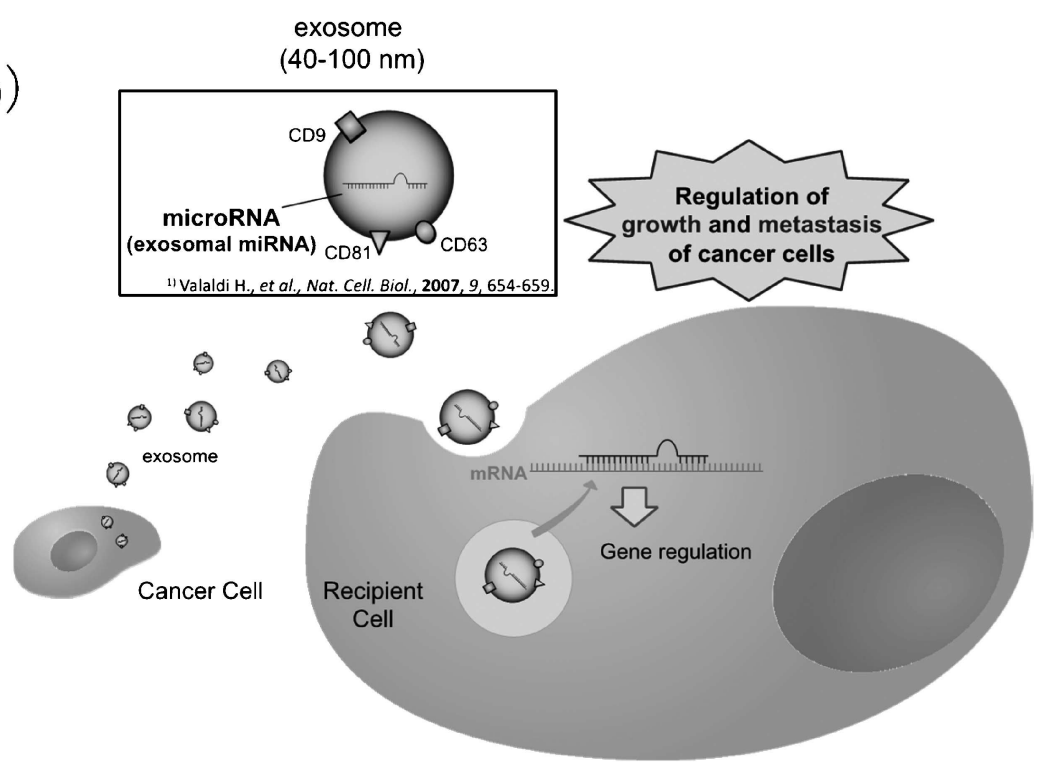

Fig. 1. (a) Mechanism of miRNA-mediated Translational Repression, and (b) Schematic Representations of the Gene Regulatory Mechanism of Exosomal miRNA in the Recipient Cells

が見い出されている. ${ }^{9)}$ また，エクソソーム表面に 存在するインテグリンのクラスターが郵便番号のよ うに機能し, 臓器選択的に送達された後, エクソ ソームが送達される臟器選択的にがん細胞が転移す る現象，すなわちがん細胞から放出されるエクソ ソームが転移先臟器に選択的に取り込まれ，前転移 ニッチ形成に寄与していることも報告されてい る. 10)このため，がんを根治するためには，がん細 胞由来エクソソームが取り込まれる細胞選択的に薬 剂を送達する技術が求められるが，エクソソーム受 容細胞選択的な drug delivery system（DDS）技術 は存在しない。本誌上シンポジウムでは, exo-
somal-miRNA を標的とした機能性分子の開発例に ついて紹介する.

\section{2. anti-miR 核酸の設計指針}

miRNA は, 細胞の分化, 増殖，代謝，アポトー シスなど，極めて重要な生命活動を制御するnoncoding RNA である. ${ }^{11,12)}$ ほ乳類遺伝子の約 $60 \%$ 以 上が miRNA による発現抑制を受けていると考えら れており， miRNAの発現異常ががんを始めとした 様々な疾患の原因の 1 つであることが知られてい る. ${ }^{13,14)}$ miRNA はそれ単独で機能せず，RNA-induced silencing complex（RISC）と呼ばれるリボヌ クレオプロテインを形成して初めてその機能を獲得 


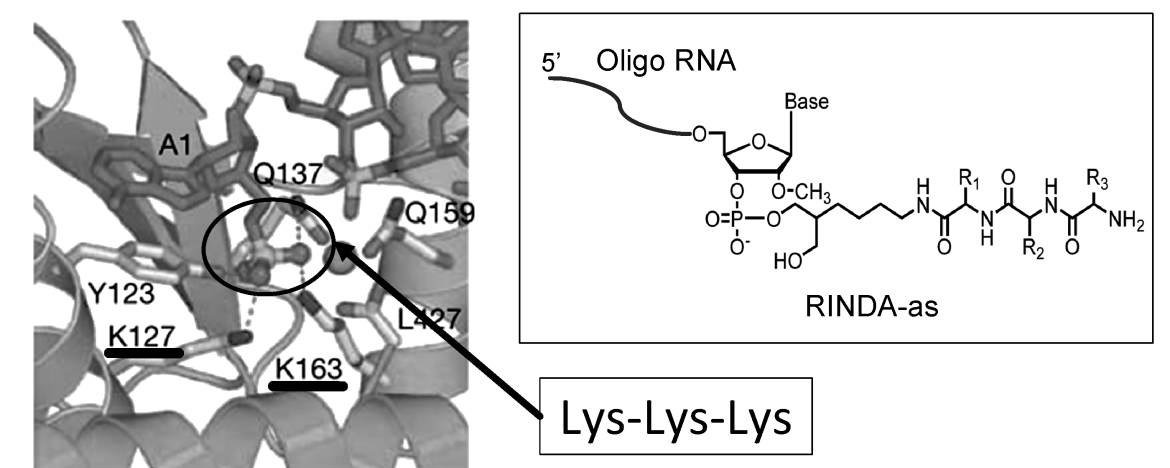

Fig. X-ray crystal structure of PIWI-box ${ }^{1)}$

Table. Kd values between microRNA and Argonaute ${ }^{1)}$

\begin{tabular}{cc}
\multicolumn{2}{c}{ Kd $(\mu \mathrm{M})$} \\
\hline Argonaute (Wild-type) & 0.19 \\
K163A & 0.73 \\
K127A & 1.46 \\
K127A/K163A & 1.56 \\
\hline
\end{tabular}
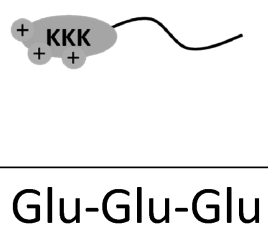

For inhibition of electrostatic interaction between 5'-phosphate of microRNA Lysine residues of PIWI-box (K127, K163)

1) J. B. Ma, et al., Nature, 2005, 434, 666-670

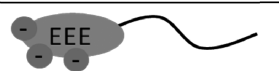

Fig. 2. Design of RINDA Peptides and Its Conjugated Oligonucleotides

する [Fig. 1(a) ]. 11,12) 一般的な anti-miR 核酸は, RISC 中の miRNA に結合することで, RISC の標 的遺伝子への結合サイトにフタをし， RISC の機能 を阻害するように分子設計するのが主流であり，現 在では様々な化学修飾が施された anti-miR 核酸が 開発されている. ${ }^{8)}$

筆者は, RISC の標的鎖認識機構における要の分 子である miRNA を RISC から解離させることで, RISC の機能を完全にノックダウンする新しい機能 性分子の開発を進めることにした。 RISCには, miRNA の 5'未端が結合する塩基性ポケット (PIWI-box) が存在し, miRNA の $5^{\prime}$ 末端と PIWIbox との相互作用が， RISC 活性に重要であること が報告されている（Fig. 2). ${ }^{15)}$ そこで筆者は，この 相互作用を阻害することで，RISC 活性を制御でき るのではないかと考えた。両者の相互作用を阻害す るペプチド・アンタゴニスト RISC-inhibitor disturbing active site of RISC (RINDA) を設計し, miRNA と相補的な配列を持つ 2'-OMe 型 RNA の 3'未端に RINDA をコンジュゲートした anti-miR 核酸（RINDA-Oligo）を合成した。 miRNA 解離効 果を評価したところ，驚くべきことに，RINDAを 導入していない anti-miR 核酸を用いた場合にも, miRNA が RISC から解離することが明らかになつ た。また，その効果は酸性アミノ酸を持つ RINDA
をコンジュゲートした RINDA（E3）-Oligo を用いた 場合に向上され, 細胞内における RISC 機能阻害効 果も促進されることが見い出された（Fig. 3). ${ }^{16)}$

上述の「RINDA を導入していない anti-miR 核 酸を用いた場合にも，RISC から miRNA が解離す る」という現象は, anti-miR 核酸による RISC 活性 の阻害機構に「miRNA が解離する」という新しい 経路が存在することを示すものである. そこで次 に，より効果的に miRNA を解離する anti-miR 核 酸の設計指針を立てるため, 現在多くの研究で用い られている化学修飾型 anti-miR 核酸の miRNA 解 離効果を評価した。 anti-miR 核酸の化学修飾とし て最も一般的に用いられている $2^{\prime}-O M e$ 型 RNA や, LNA が修飾された anti-miR 核酸の miRNA 解離速 度 $\left(T_{1 / 2}\right)$, 標的 miRNA に対する結合親和性 $\left(T_{\mathrm{m}}\right.$ 值)， RISC 活性阻害効果（ $\mathrm{IC}_{50}$ ) の三者の相関性を 評価した。 その結果, 標的 miRNA に対する $T_{\mathrm{m}}$ 值 が高い anti-miR 核酸は, miRNA 解離速度 $\left(T_{1 / 2}\right)$ が速いことが明らかになつた。ささらに, miRNA 解 離速度 $\left(T_{1 / 2}\right)$ が速い anti-miR 核酸は, RISC 活性 阻害効果 $\left(\mathrm{IC}_{50}\right)$ が高いことも示された. ${ }^{17,18)}$ これ らの結果から，標的 miRNA に対して高い結合親和 性を有する anti-miR 核酸は高い miRNA 解離効果 を示し，その結果，効果的に RISC の活性を阻害す るという新たな作用機構が見い出された. 


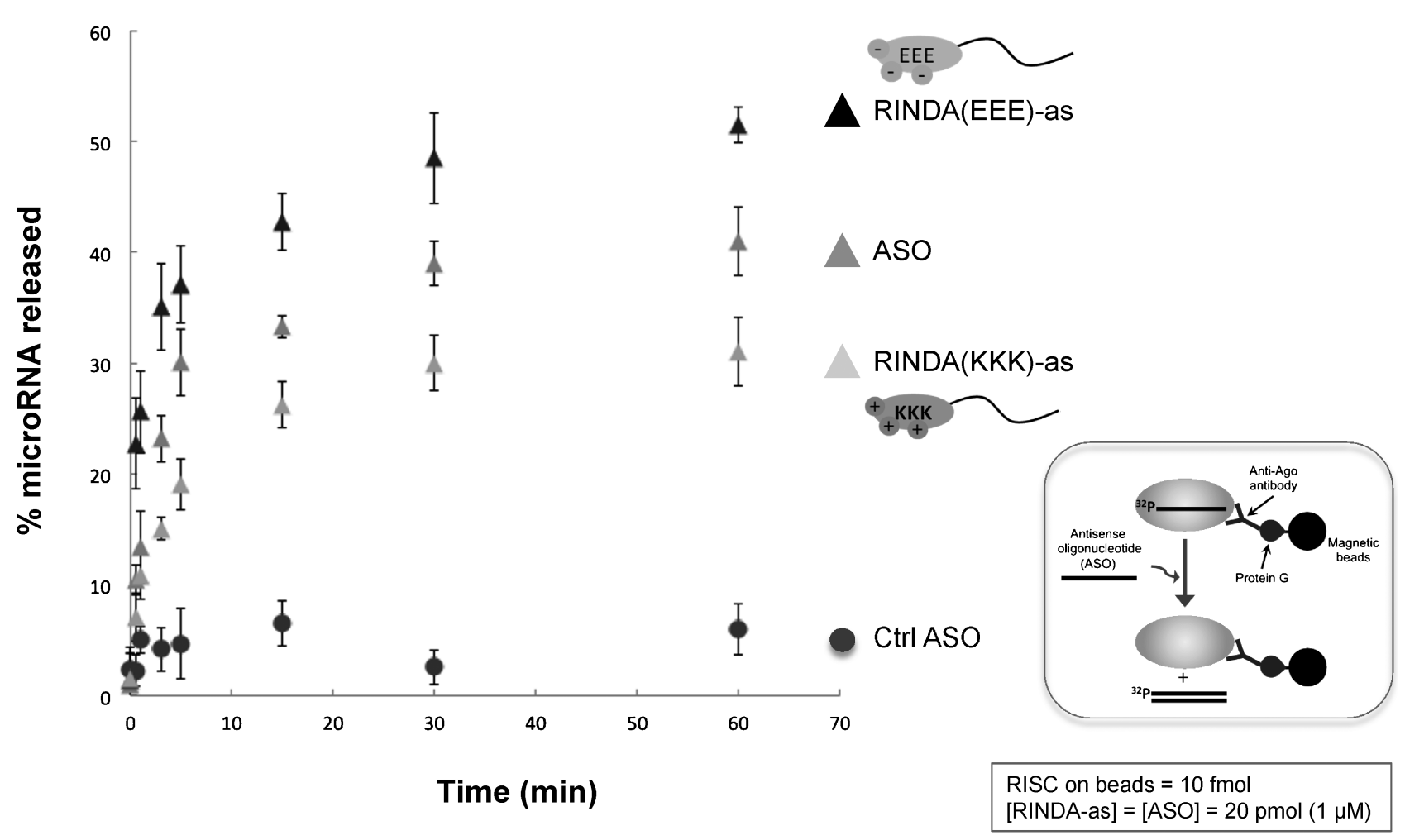

Fig. 3. Releasing Rates of miRNA from RISC by Using RINDA-conjugated Oligonucleotides

anti-miR 核酸が RISC 中の miRNA に結合した後 の運命に関しては，様々な議論がなされながらも明 解な解答がない状態だった。われわれは anti-miR 核酸によって miRNA が RISC から解離する現象を 見い出した。この知見から，これまでとは異なった 作用機序に立脚した miRNA 阻害剂の開発も期待さ れる。

3. exosomal-miRNA を標的とした抗体結合型 anti-miR 核酸の開発

上記項目で anti-miR 核酸の分子構造の最適化を 行った後, exosomal-miRNAの機能阻害を目指し た anti-miR 核酸の DDS 戦略開発に着手した。先述 したように, exosomal-miRNA は体内を巡り，受 容細胞内で機能するため, exosomal-miRNA を標 的とした創薬を考える場合，薬剤をエクソソーム受 容細胞に送達する技術が求められる。そこで筆者 は，エクソソーム表面抗原を認識する抗体（antiExo 抗体）を薬物輸送担体として利用することで, anti-miR 核酸のエクソソーム受容細胞への送達と, exosomal-miRNAの機能阻害を実現するエクソ ソーム随伴導入型核酸医薬 (ExomiR-Tracker) の 開発を行った。ExomiR-Tracker は「anti-Exo 抗体」
に「anti-miR 核酸」が導入された「抗体結合型核 酸」である。戦略としては，体液中で ExomiRTracker の anti-Exo 抗体部分がエクソソーム表面に 結合した後，エクソソーム受容細胞内に導入される 際に, ExomiR-Tracker の anti-miR 核酸も細胞内部 に導入されるのではないかというものである.

当初，このコンセプトが実現可能かどうかについ て十分な知見がなかったため，まず，anti-Exo 抗体 に蛍光標識を施し, Cal27 細胞（口腔上皮がん細胞） の培養細胞上清に添加して, 細胞内に導入されるか どうかを評価した。 anti-Exo 抗体として，anti-CD9 抗体, anti-CD63 抗体, anti-CD81 抗体を使用し た。 またコントロールとして，エクソソーム内部に 存在する TSG101 タンパク質を抗原とする antiTSG101 抗体を用いた．共焦点レーザー顕微鏡によ る観察の結果, anti-TSG101 抗体の場合には蛍光が 全く観察されなかつたが，anti-Exo 抗体の場合に は，程度の差はあるものの，いずれの場合にも蛍光 が細胞質中に認められた。 とりわけ, anti-CD63 抗 体を用いた場合に細胞質にその蛍光が顕著に観察さ れたため, anti-CD63 抗体を ExomiR-Tracker とし て採用することとした。 


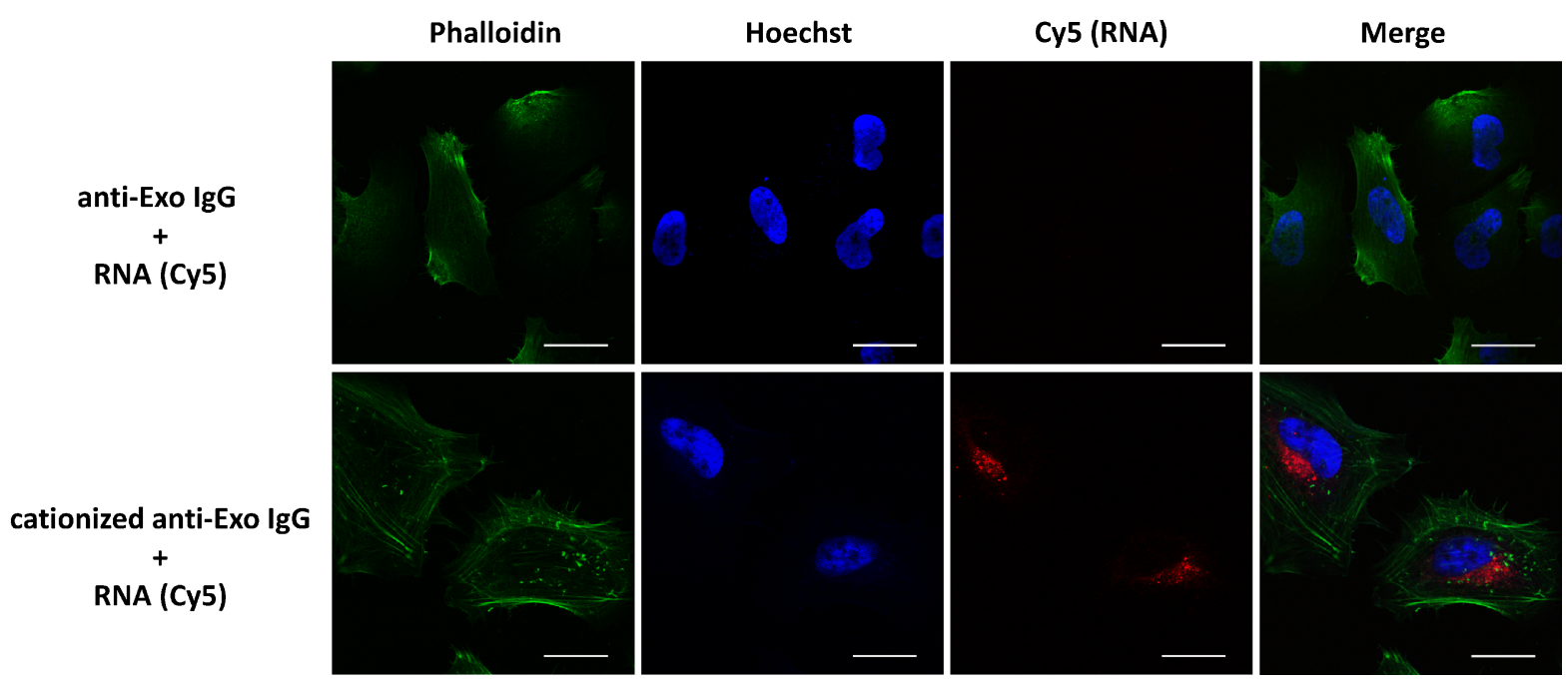

Fig. 4. Confocal Microscopic Images $(\times 100)$ of Cells Treated with anti-Exo mAb + RNA (Cy5) or anti-Exo mAb-9r + RNA (Cy5) Blue: Hoechst 33342 (nuclei); Green: Acti-stain 488; Red: RNA (Cy5); [mAb] $=200 \mathrm{nM}$, Scale Bars: $30 \mu \mathrm{m}$. (Color figure can be accessed in the online version.)

次に, anti-CD63 抗体を用い, ExomiR-Tracker の合成を行った。本研究では, anti-Exo 抗体と anti-miR 核酸を結合させるリンカーとしてアルギ ニンリッチなオリゴペプチドを採用した。まず,

Traut's Reagent（Thermo Scientific）を用い，抗体 （IgG）のアミノ基を介してチオール基を導入した. チオール基の導入量は Ellman's Reagent（Thermo Scientific）により行った。 そして，チオール基が修 飾された IgGに対して Cys (Npys) - (D-Arg) (AnaSpec) を加え，ジスルフィド結合形成反応に よるオリゴアルギニンペプチドの導入を行った. $\mathrm{IgG}$ に対するアルギニンの導入の有無は, anti-miR 核酸とのゲルシフトアッセイにより確認した．最後 にアルギニンが導入された IgG と anti-miR 核酸と を phosphate buffered saline (PBS) 中で混合し, 両者の複合体（ExomiR-Tracker）を得た。また, コントロール分子として anti-TSG101 抗体を用 い，上記と同様にアルギニンを導入し， anti-miR 核酸との複合体を作製した（Ctrl IgG-antimiR complex).

蛍光標識した ExomiR-Tracker を培養細胞上清に 添加し共焦点レーザー顕微鏡により観察したとこ ろ，細胞質に局在することが確認された。一方, anti-Exo 抗体並びに anti-miR 核酸を単独投与した 系, Ctrl IgG-antimiR complex 添加系においては, 細胞内に蛍光シグナルが認められなかった（Fig. 4)。この結果より, ExomiR-Tracker はエクソソー
ムを介して細胞内に導入されることが示唆された。

ExomiR-Trackerに搭載された anti-miR 核酸が細 胞内に導入されることが確認されたため, 細胞内に 導入された anti-miR 核酸が遺伝子発現抑制効果を 発揮するかどうかについて評価することとした。本 研究では exosomal miR-21 を anti-miR 核酸の標的 として選定した。低酸素条件下で培養した口腔上皮 がん細胞では，エクソソームに含まれる miRNAの うち miR-21 の量が増大し，エクソソーム受容細胞 の増殖能，転移能などを促進させることが知られて いる. ${ }^{19)}$ 筆者らも口腔上皮がん細胞（Cal-27）を通 常酸素条件下 $\left(20 \% \mathrm{O}_{2}\right)$ 及び低酸素条件下 $(0.1 \%$ $\mathrm{O}_{2}$ ）でそれぞれ培養後, 超遠心法を用いてエクソ ソームを培養上清から回収し, qRT-PCRにより解 析した結果，低酸素条件下で培養した細胞由来の exosomal miR-21 の量は, 通常酸素条件下で培養し たものより約 3.5 倍増大していることが確認され,

エクソソーム受容細胞の増殖を六進することを確認 している. miR-21 を標的とした anti-miR 核酸を搭 載した ExomiR-Trackerを合成し， exosomalmiR21に対する機能阻害能をルシフェラーゼレ ポーターアッセイにより評価した. その結果, ExomiR-Tracker は標的 miRNA の機能を配列特異的に 阻害することが可能であることが示された。 さらに, Scratch Assay により細胞増殖抑制効果を評価した 結果, Hypoxiaエクソソーム添加系において促進さ れた細胞増殖に対し，ExomiR-Tracker は顕著な抑 
制効果を示すことが明らかとなった.

最後に，ヌードマウスを用いて担がんマウスを作 製し臓器分布について評価したところ，ExomiRTracker は腫瘍へ選択的に集積することが明らかと なった. さらに, 顕著な抗腫瘍効果も確認された. 今後, ExomiR-Tracker の細胞内導入機構や作用機 序について，さらに詳細に解析していく予定である.

\section{4. まとめ}

筆者は，極微量で高度な機能を発揮し，生体制御 系に大きな役割を果たしている exosomal-miRNA を標的とした機能性分子の開発に成功した。近年, エクソソームを回収した後, 様々な分子を内包させ ることで DDS として利用する研究が盛んに行われ ているが, ${ }^{20,21)}$ 筆者らの開発した手法はエクソソー ムを単離・精製する必要がなく，体内に直接投与で きるという点において一線を画すものである. エク ソソームには miRNA 以外の non-coding RNA や, mRNA，MMPなどのタンパク質が含まれており， がん化に寄与するものが次々と報告されている，筆 者らの開発した ExomiR-Tracker は, anti-miR 核酸 でなく，mRNAを標的としたアンチセンス核酸, siRNA，アプタマー，さらには核酸だけでなく低分 子化合物を導入することも可能である，今後, exosomal-miRNA だけでなく，エクソソームに内包さ れる様々な分子を標的とした新規分子標的医薬の創 製へと発展させていきたい.

謝辞 本研究にご協力頂いた京都工芸繊維大学 大学院工芸科学研究科の村上 章教授並びに有吉純 平博士，岸本祐典修士，小西 諒修士を始めとする 生体高分子情報研究室の学生の皆様, 京都大学大学 院理学研究科の杉山 弘教授, 長崎大学大学院医歯 薬学総合研究科の山本剛史准教授及び機能性分子化 学研究室の大山将大学士, 大日本住友製薬株式会社 の関係者各位に深く感謝致します。

利益相反 大日本住友製薬 (株)から共同研究費 を受領.

\section{REFERENCES}

1) Valadi H., Ekström K., Bossios A., Sjöstrand M., Lee J. J., Lötvall J. O., Nat. Cell Biol., 6, 654-659 (2007).
2) Kosaka N., Iguchi H., Yoshioka Y., Takeshita F., Matsuki Y., Ochiya T., J. Biol. Chem., 285, 17442-17452 (2010).

3) Valadi H., Ekström K., Bossios A., Sjöstrand M., Lee J. J., Lötvall J. O., Nat. Cell Biol., 9, 654-659 (2007).

4) Pegtel D. M., Cosmopoulos K., ThorleyLawson D. A., van Eijndhoven M. A., Hopmans E. S., Lindenberg J. L., de Gruijl T. D., Würdinger T., Middeldorp J. M., Proc. Natl. Acad. Sci. USA, 107, 6328-6333 (2010) .

5) Zhang Y., Liu D., Chen X., Li J., Li L., Bian Z., Sun F., Lu J., Yin Y., Cai X., Sun Q., Wang K., Ba Y., Wang Q., Wang D., Yang J., Liu P., Xu T., Yan Q., Zhang J., Zen K., Zhang C.Y., Mol. Cell, 39, 133-144 (2010).

6) Kosaka N., Iguchi H., Yoshioka Y., Takeshita F., Matsuki Y., Ochiya T., J. Biol. Chem., 285, 17442-17452 (2010).

7) Peinado H., Alečković M., Lavotshkin S., Matei I., Costa-Silva B., Moreno-Bueno G., Hergueta-Redondo M., Williams C., GarcíaSantos G., Ghajar C., Nitadori-Hoshino A., Hoffman C., Badal K., Garcia B. A., Callahan M. K., Yuan J., Martins V. R., Skog J., Kaplan R. N., Brady M. S., Wolchok J. D., Chapman P. B., Kang Y., Bromberg J., Lyden D., Nat. Med., 18, 883-891 (2012).

8) Horwich M. D., Zamore P. D., Nat. Protoc., 3, 1537-1549 (2008).

9) Toda Y., Takata K., Nakagawa Y., Kawakami H., Fujioka S., Kobayashi K., Hattori Y., Kitamura Y., Akaji K., Ashihara E., Biochem. Biophys. Res. Commun., 456, 768773 (2015).

10) Hoshino A., Costa-Silva B., Shen T. L. Rodrigues G., Hashimoto A., Tesic Mark M., Molina H., Kohsaka S., Di Giannatale A., Ceder S., Singh S., Williams C., Soplop N., Uryu K., Pharmer L., King T., Bojmar L., Davies A. E., Ararso Y., Zhang T., Zhang H., Hernandez J., Weiss J. M., Dumont-Cole V. D., Kramer K., Wexler L. H., Narendran A., Schwartz G. K. Healey J. H., Sandstrom P., Labori K. J., Kure E. H., Grandgenett P. M., Hollingsworth M. A., de Sousa M., Kaur S., Jain M., Mallya K., Batra S. K., Jarnagin W. R., Brady M. S., Fodstad O., Muller V., Pantel K., Minn A. J., Bissell M. J., Garcia B. A., 
Kang Y., Rajasekhar V. K., Ghajar C. M., Matei I., Peinado H., Bromberg J., Lyden D., Nature, 527, 329-335 (2015).

11) Ambros V., Nature, 431, 350-355 (2004).

12) Kloosterman W. P., Plasterk R. H., Cell, 11, 441-450 (2006).

13) Krol J., Leodige I., Filipowicz W., Nat. Rev. Genet., 11, 597-610 (2010).

14) Ma L., Breast Cancer Res., 12, 210 (2010).

15) Ma J. B., Yuan Y. R., Meister G., Pei Y., Tuschl T., Patel D. J., Nature, 434, 666-670 (2005).

16) Ariyoshi J., Momokawa D., Eimori N., Kobori A., Murakami A., Yamayoshi A., Bioconjug. Chem., 26, 2454-2460 (2015).

17) Ariyoshi J., Eimori N., Kobori A., Murakami
A., Sugiyama H., Yamayoshi A., Chem. Lett., 46, 143-145 (2017).

18) Ariyoshi J., Matsuyama Y., Kobori A., Murakami A., Yamayoshi A., Nucleic Acids Ther., 27, 303-308 (2017).

19) Li L., Chao L., Wang S., Wang Z., Jiang J., Wang W., Li X., Chen J., Liu K., Li C., Zhu G., Cancer Res., 76, 1770-1780 (2016).

20) Lai C. P., Mardini O., Ericsson M., Prabhakar S., Maguire C., Chen J. W., Tannous B. A., Breakefield X. O., ACS Nano, 8, 483494 (2014).

21) Smyth T., Petrova K., Payton N. M., Persaud I., Redzic J. S., Graner M. W., Smith-Jones P., Anchordoquy T. J., Bioconjug. Chem., 25, 1777-1784 (2014). 